\title{
Corrigendum: Microdroplet-based PCR enrichment for large-scale targeted sequencing
}

Ryan Tewhey, Jason B Warner, Masakazu Nakano, Brian Libby, Martina Medkova, Patricia H David, Steve K Kotsopoulos, Michael L Samuels, J Brian Hutchison, Jonathan W Larson, Eric J Topol, Michael P Weiner, Olivier Harismendy, Jeff Olson, Darren R Link \& Kelly A Frazer Nat. Biotechnol. 27, 1025-1031 (2009); published online 1 November 2009; corrected after print 11 November 2009

In the version of this article initially published, the email address for K.A.F. should have been kafrazer@ucsd.edu. The error has been corrected in the HTML and PDF versions of the article.

\section{Corrigendum: The valuation high ground}

Jeffrey J Stewart \& Ben Bonifant

Nat. Biotechnol. 27, 980-983 (2009); published online 24 September 2009; corrected online 6 November 2009; pdf corrected 5 February 2010

In the version of this article initially published, the email address for Ben Bonifant was incorrect. The email address is bbonifant@campbellalliance. com. The error has been corrected in the HTML and PDF versions of the article.

\section{Corrigendum: Receptor-binding specificity of pandemic influenza A (H1N1) 2009 virus determined by carbohydrate microarray}

Robert A Childs, Angelina S Palma, Steve Wharton, Tatyana Matrosovich, Yan Liu, Wengang Chai, Maria A Campanero-Rhodes, Yibing Zhang, Markus Eickmann, Makoto Kiso, Alan Hay, Mikhail Matrosovich \& Ten Feizi

Nat. Biotechnol. 27, 797-799 (2009); published online 9 September 2009; corrected after print 5 February 2010

In the version of this article initially published, two acknowledgments were inadvertently omitted: NCI Alliance of Glycobiologists for Detection of Cancer and Cancer Risk; and Biotechnology and Biological Sciences Research Council. The error has been corrected in the HTML and PDF versions of the article.

\section{Corrigendum: Small but not simple}

Markus Elsner

Nat. Biotechnol. 28, 42 (2010); published online 8 January 2010; corrected after print 5 February 2010

In the version of this article initially published, the organisms in question were incorrectly identified as Mycobacterium pneumoniae and Mycobacterium genitalium. The correct names are Mycoplasma pneumoniae and Mycoplasma genitalium, respectively. The error has been corrected in the HTML and PDF versions of the article.

\section{Erratum: A nuclear magnetic resonance technique for determining hybridoma cell concentration in hollow fiber bioreactors}

Anthony Mancuso, Erik J. Fernandez, Harvey W. Blanch \& Douglas S. Clark

Biotechnology 8, 1282-1285 (1990); corrected online 5 February 2010

In the version of this article initially published online, a graph published in print as Figure 2 was erroneously duplicated and appeared as both Figure 1 and Figure 2. The original Figure 1 has been restored in the online PDF version of the article.

\section{Erratum: Can web 2.0 reboot clinical trials?}

Malorye Allison

Nat. Biotechnol. 27, 895-902 (2009); published online 8 October 2009; corrected after print 5 February 2010

In the version of this article initially published, Sharib Khan was incorrectly identified as the CEO of TrialX. He is cofounder. The error has been corrected in the HTML and PDF versions of the article. 